\title{
Abnormal hemoglobin variants, $A B O$, and Rhesus blood group distribution among students in the Niger Delta of Nigeria
}

This article was published in the following Dove Press journal:

Pathology and Laboratory Medicine International

29 April 2010

Number of times this article has been viewed

O Erhabor'

TC Adias ${ }^{2}$

Z A Jeremiah'

M L Hart ${ }^{2}$

'Department of Medical Laboratory Sciences, College of Health Sciences, Niger Delta University, Wilberforce Island, Bayelsa State, Nigeria; ${ }^{2}$ Department of Medical Laboratory Sciences, Rivers State University of Science and Technology, Port Harcourt, Nigeria
Correspondence: Osaro Erhabor

Blood Sciences Department,

Royal Bolton Hospital, Bolton,

Lancashire, UK

Tel +447932363217

Email n_osaro@yahoo.com
Background: Communities in Africa constitute a major part of the population that is vulnerable to many erythrocytic hereditary and hematological disorders such as hemoglobinopathies. The frequencies of abnormal hemoglobin variants, ABO, and Rhesus blood groups vary from one population to another.

Methods: The aim of this study was to find the prevalence/spectrum of hemoglobin variants, ABO, and Rhesus blood group distribution among 204 undergraduate students of African descent in Port Harcourt in the heart of the Niger Delta geopolitical zone of Nigeria. Standard alkaline cellulose acetate electrophoretic technique using the Shandon electrophoretic tank with tris-ethylene diamine tetracetic acid (EDTA) borate buffer and hemagglutination techniques were employed for the determination of abnormal hemoglobin variants, $\mathrm{ABO}$ and Rhesus blood groups, respectively.

Results: Two hundred and four apparently healthy students of African descent comprising 124 males (60.8\%) and $80(39.2 \%)$ females with a mean age $24.5 \pm 6.5$ years took part in the study. Subjects were screened for abnormal hemoglobin variants, ABO, and Rhesus groups. Normal hemoglobin accounted for $69.1 \%$, followed by abnormal sickle cell trait in $29.4 \%$, and the sickle cell disease in $1.5 \%$ of the study population. The distribution of the various blood groups indicated that $46 \%$ were blood group O, 26.6\% were group A, $23.6 \%$ were group $\mathrm{B}$ while $3.8 \%$ were group $\mathrm{AB}$. Rhesus $(\mathrm{RhD})$ positivity rate was $93 \%$ while $\mathrm{RhD}$ negativity accounted for $7 \%$.

Conclusion: This research indicates a high prevalence of hemoglobin variants in the study population. Carrier screening and mutation identification can become the cornerstones of any prevention program for hemoglobin disorders. It can also help in the formulation of genetic counseling policies to help prospective couples make informed decisions in a bid to reduce the sickling gene pool in the Niger Delta of Nigeria.

Keywords: abnormal hemoglobin variants, ABO, Rhesus blood group, Niger Delta, Nigeria

\section{Introduction}

Abnormal hemoglobin variants are a group of autosomal recessive disorders characterized by the synthesis of a structurally abnormal globin chain. Inherited disorders of hemoglobin are the most common gene disorders with $7 \%$ of the world's population being carriers. ${ }^{1}$ Worldwide, it is estimated that there about 240,000 healthy carriers of the sickle gene variants and 300,000 children are born with sickle cell disease (SCD) every year. ${ }^{2}$ Sickle cell disorders are estimated to affect more than 1 in 2400 births in England. ${ }^{2}$ The highest prevalence of the sickle cell disorders is found amongst people of African or West Indian (Caribbean) descent. ${ }^{2}$ It may also occur in 
people from the eastern Mediterranean, Middle East, India, and Pakistan. ${ }^{2}$ In countries located in malarious regions of the world, a few of the mutations have reached high gene frequencies because of the protection they provide against malaria. ${ }^{1}$ Sickling disorders include the heterozygous state for hemoglobin $\mathrm{S}(\mathrm{HbS})$ or the sickle cell trait (AS), the homozygous state for HbS or sickle cell anemia (SS), and the compound heterozygous state for $\mathrm{HbS}$ together with other hemoglobin $(\mathrm{C}, \mathrm{D}, \mathrm{E})$ or other structural variants. Hemoglobin S differs from hemoglobin A by the substitution of the amino acid valine for glutamic acid at position 6 in the $\beta$-chain. The prevalence of sickle cell anemia (HbSS) among the black population in the United States is reported to be $9 \%{ }^{3}$ and $30 \%-40 \%$ generally for Africans. ${ }^{4}$

The membrane of the human red blood cell (RBC) is complex and contains a variety of blood group antigens, the most clinically significant being the A and B antigens. These antigens are actually complex oligosaccharides that differ in their terminal sugar. The antibodies against red cell antigens are called agglutinins and individuals are categorized into one of four major ABO blood groups ( $\mathrm{A}, \mathrm{B}, \mathrm{AB}$, or $\mathrm{O}$ ) according to the presence or absence of $A$ and $B$ antigens and agglutinins. ${ }^{5,6}$ In addition, human red blood cells that contain antigen $\mathrm{D}$ and are known as known as Rhesus positive while those without antigen D in their RBC's are Rhesus negative. The clinical relevance of these blood group systems relates to the capacity of alloantibodies (directed against antigens not possessed by the individual) to cause destruction of transfused red cells (ABO antibodies) or to cross the placenta and give rise to hemolytic disease of a newborn (HDN). ${ }^{7}$

Knowledge of the distribution of the various blood groups and abnormal hemoglobin variants is vital in determining the type and stock levels to be maintained in the hospital blood bank as well as in the formulation of transfusion policies. As an example, patients with sickle cell disease are often faced with the risk of alloimmunization from allogeneic blood transfusions. Carrier screening and mutation identification, therefore, can form one of the cornerstones of any prevention program for the hemoglobin disorders. The strategy for carrier screening and mutation analysis is based on that fact that although heterozygotes are symptom free, they present specific hematologic characteristics that are useful for their identification.

The most populous country in Africa, Nigeria accounts for approximately one-sixth of Africa's people. The variety of customs, languages, and traditions among Nigeria's 389 ethnic groups gives the country a cultural diversity. The Niger Delta of Nigeria is a densely populated oil-producing region. The Niger Delta, as now defined officially by the Nigerian Government, extends over about $70,000 \mathrm{~km}^{2}$ and makes up $7.5 \%$ of Nigeria's land mass. Historically and cartographically, it consists of 9 of the 36 states in Nigeria: Bayelsa, Rivers, Delta, Abia, Akwa Ibom, Cross River, Edo, Imo, and Ondo. Some 31 million people belonging to more than 40 ethnic groups including the Efik, Ibibio Annang, Oron, Ijaw, Itsekiri, Igbo, Urhobo, and Kalabari are among some who speak approximately 250 dialects in the Niger Delta. This study aimed to determine the prevalence/spectrum of hemoglobin variants, $\mathrm{ABO}$ and $\mathrm{RhD}$ blood group distribution among 204 undergraduate students of African descent from the ethnic groups of the Niger Delta of Nigeria attending the Rivers State University of Science and Technology in Port Harcourt.

\section{Materials and methods Study population}

Participants were selected randomly and drawn from adult students of African descent from the Niger Delta of Nigeria attending the University of Science and Technology in Port Harcourt, Nigeria. A total of two hundred four (204) participants (124 males and 80 females, aged $\geq 18$ years, mean age 24.5 years and $95 \%$ confidence range of 18-31 years) were enrolled into this study. The study was carried out in the Laboratory Department of Omoku General Hospital. The institutional ethical committee approved the study. All the participants gave their written, informed consent and were offered pre- and post-test counseling.

\section{Sample collection and laboratory methods}

As mentioned, this study aimed to find the prevalence/ spectrum of hemoglobin variants, $\mathrm{ABO}$, and Rhesus blood group distribution among 204 undergraduate participants of African descent from the Niger Delta geopolitical zone of Nigeria.

Blood samples were collected by venipuncture into ethylene diamine tetracetic acid (EDTA) anticoagulated tubes and used for the determination of abnormal hemoglobin variants and red cell phenotyping. The method described by Brown ${ }^{8}$ was used for hemoglobin electrophoresis. A small quantity of hemolysate of venous blood from each of the subjects was placed on a cellulose acetate membrane and carefully introduced into the electrophoretic tank containing tris-EDTA-borate buffer at $\mathrm{pH}$ 8.6. Electrophoretic separation was then allowed to operate 
for 15-20 minutes at an electro motive force (emf) of $160 \mathrm{~V}$. The results were read immediately. Hemolysate from blood samples of known hemoglobin (AA, AS, AC) were run as controls. Red cell phenotyping was carried out with standard tube techniques as described by Judd ${ }^{9}$ and Brecher. ${ }^{10}$ For ABO blood grouping, a drop each of anti-A, anti-B, and anti-AB reagents (Biotec, Ipswich, UK) was placed in clean test tubes labeled 1, 2, and 3. To each tube a drop of $5 \%$ red blood cell suspension in saline was added. The contents were gently mixed together and centrifuged for 30 seconds at $1000 \mathrm{~g}$. The cell buttons were re-suspended and observed for agglutination. Agglutination of tested red cells constituted positive results. A smooth cell suspension after re-suspension followed by a microscopic confirmation constituted negative test results. For Rhesus D typing, a drop of anti-D serum (Biotec) was placed in a clean, labeled test tube and a drop of control was placed in a second tube. One drop of 5\% RBC suspension in saline was then added and incubated at $37^{\circ} \mathrm{C}$. At the end of the incubation period, the contents of the tube were mixed gently and centrifuged for 30 seconds at 1000 g. Agglutination was read macroscopically and microscopically in doubtful cases. All negative results were confirmed using the indirect antiglobulin test (IAT) procedure for confirmation of weak D.

\section{Statistical analysis}

Statistical analysis was analyzed using computer database software from the Statistical Package for Social Sciences (version 10; SPSS Inc., Chicago, IL) to generate frequency distribution and percentage prevalence scores of the various parameters. Descriptive analysis of the percentages of continuous variables was reported. Comparisons were assessed using mean and chi-square tests. A $P$-value of $<0.05$ was considered statistically significant in all clinical comparisons.

\section{Results}

A total of 204 participants were screened for ABO, Rhesus blood groups and abnormal hemoglobin variants. Out of the 204 apparently healthy students of African descent made up of 124 males $(60.8 \%)$ and $80(39.2 \%)$ females with a mean age $24.5 \pm 6.5$ years screened, 141(69.1\%) subjects had (normal hemoglobin [HbAA]), 60 (29.4\%) had (abnormal sickle cell trait $[\mathrm{HbAS}])$, and $3(1.5 \%)$ had (HbSS). None of the participants had abnormal pattern AC or SC. Figure 1 shows the distribution of the abnormal hemoglobin variants among the study participants. The distribution of abnormal hemoglobin variant was further compared based on gender (Table 1). Fifty eight (41.1\%) males and 83 (58.8\%) females had (HbAA), 23 (38.3\%) males and 37 (61.7\%) had (HbAS) while $1(3 \%)$ male and $2(6 \%)$ females had (HbSS).

The distribution of the various blood groups revealed that $66(46 \%)$ were group O, $26(26.6 \%)$ were group A, $22(23.6 \%)$ were group B, while $2(3.8 \%)$ were group AB. (Table 2). The distribution of ABO and Rhesus blood groups of the all study participants is shown in Table 2. ABO groups were further compared based on gender (Table 3 ). The distribution of ABO blood groups showed that $32.3 \%$ of males and $13.7 \%$ of females were group $\mathrm{O}, 12.8 \%$ and $13.8 \%$ were group A, $12.7 \%$ and $10.9 \%$ were group B while $2.9 \%$ of males $0.9 \%$ of females were group AB. Rhesus positivity rate was 190 (93\%) while negativity accounted for $14(7 \%)$ for the total population studied. The distribution of the percentage frequency of Rhesus D groups among the study participants showed that 116 (56.9\%) of males

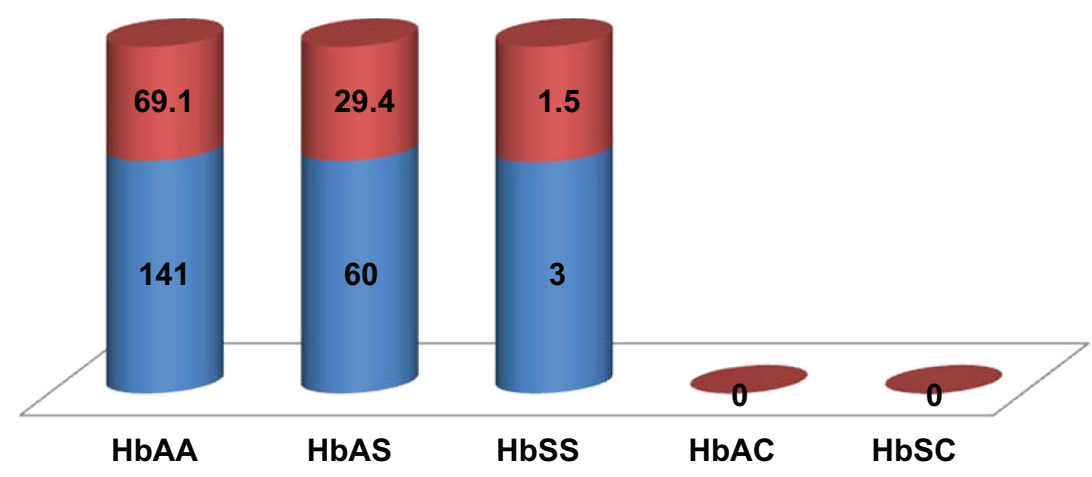

Number Tested

$\%$ Tested

Figure I Distribution of abnormal hemoglobin variants among participants

Abbreviations: HbAA, normal hemoglobin; HbAC, hemoglobin C trait; HbAS, abnormal sickle cell trait; HbSC, hemoglobin SC disease; HbSS, sickle cell anemia. 
Table I Distribution of the abnormal hemoglobin variants based on gender

\begin{tabular}{llllll}
\hline Gender & HbAA (\%) & HbAS (\%) & HbSS (\%) & HbAC (\%) & HbSC (\%) \\
\hline Male & $58(41.1 \%)$ & $23(38.3 \%)$ & I (3\%) & nil & nil \\
Female & $83(58.8 \%)$ & $37(61.7 \%)$ & $2(6 \%)$ & nil & nil
\end{tabular}

Abbreviations: $\mathrm{HbAA}$, normal hemoglobin; $\mathrm{HbAC}$, hemoglobin $\mathrm{C}$ trait; $\mathrm{HbAS}$, abnormal sickle cell trait; $\mathrm{HbSC}$, hemoglobin SC disease; $\mathrm{HbSS}$, sickle cell anemia.

and 74 females (36.2\%) were RhD positive. By contrast, 8 males (3.9\%) and $6(2.9 \%)$ females were $\mathrm{RhD}$ negative (Table 3).

\section{Discussion}

In this study on a small population from the Niger Delta of Nigeria, we observed a prevalence of $69.1 \%, 29.4 \%$, and $1.5 \%$ for $\mathrm{HbAA}, \mathrm{HbAS}$, and $\mathrm{HbSS}$, respectively. By comparison, the prevalence of $\mathrm{HbSS}$ among the black population in the United States is reported to be $9 \%$ and $30 \%-40 \%$ generally for Africans. ${ }^{3,4}$ In another report the geographical distribution of SS was given as follows: $3 \%-9 \%$ for black Americans, $1 \%-8 \%$ for white Americans, $3 \%-7 \%$ for Europeans (United Kingdom among Pakistanis and blacks), 2\%-8\% for other European countries (Mediterranean), $1 \%-3 \%$ for Caribbeans, $1 \%-3 \%$ for Middle East, $1 \%-10 \%$ for Africans. The frequency of (AS) was reported as follows: $8 \%-16 \%$ for black Americans, $8 \%-10 \%$ for white Americans, 6\%-15\% for Europeans (United Kingdom, Pakistanis and blacks), $1 \%-15 \%$ for Europeans (Mediterranean), 3\%-8\% for Caribbeans, $7 \%-8 \%$ for Middle Easterns, $15 \%-30.5 \%$ for Africans, and $40.5 \%$ for West Africanerns, and Nigerians. ${ }^{11}$

Our finding of a prevalence of $29.4 \% \mathrm{HbAS}$ and $1.5 \%$ $\mathrm{HbSS}$ is consistent with previous reports among undergraduate students in Bayelsa state ${ }^{12}$ and Rivers state, ${ }^{13}$ both in the South-South of Nigeria where prevalence rates for $\mathrm{HbSS}$ of $2 \%$ and $3 \%$, respectively, were observed. However, a study carried out in Kenya, East Africa observed a $0 \%$ prevalence of $\mathrm{HbSS}$. Instead the authors observed a prevalence of $74 \%$ and $97 \%$ for $\mathrm{HbAA}$ in lowland and

Table 2 Distribution of $A B O$ and Rhesus blood groups

\begin{tabular}{llll}
\hline $\begin{array}{l}\text { ABO blood } \\
\text { group }\end{array}$ & $\begin{array}{l}\text { Number of } \\
\text { subjects (\%) }\end{array}$ & $\begin{array}{l}\text { Number of } \\
\text { subjects (\%) } \\
\text { Rh-positive }\end{array}$ & $\begin{array}{l}\text { Number of } \\
\text { subjects (\%) } \\
\text { Rh-negative }\end{array}$ \\
\hline A & $54(26.5)$ & $52(25.5)$ & $2(0.98)$ \\
B & $48(23.5)$ & $44(21.6)$ & $4(1.96)$ \\
AB & $8(3.9)$ & $6(2.9)$ & $2(0.98)$ \\
O & $94(46.1)$ & $88(43.1)$ & $6(2.94)$ \\
\hline
\end{tabular}

Table 3 Distribution of $A B O$ and Rhesus blood groups based on gender

\begin{tabular}{lllllll}
\hline $\begin{array}{l}\text { Gender } \\
\text { A (\%) }\end{array}$ & $\begin{array}{l}\text { B (\%) } \\
\text { B }\end{array}$ & $\begin{array}{l}\text { AB (\%) } \\
\text { O (\%) }\end{array}$ & $\begin{array}{l}\text { Rh- } \\
\text { positive } \\
(\%)\end{array}$ & $\begin{array}{l}\text { Rh- } \\
\text { negative } \\
(\%)\end{array}$ \\
\hline Male & $26(12.8)$ & $26(12.7)$ & $6(2.9)$ & $66(32.3)$ & $116(56.8)$ & $8(3.9)$ \\
Female & $28(26.6)$ & $22(10.9)$ & $2(0.9)$ & $28(13.7)$ & $74(36.2)$ & $6(2.9)$ \\
\hline
\end{tabular}

highland areas and 26\% and 3\% for HbAS in lowland and highland areas, respectively. ${ }^{14}$ The zero frequencies observed in this study possibly imply that the sickling gene pool may gradually be reducing in some African populations, particularly those with an abnormal hemoglobin carrier screening and genetic counseling program for the prevention of hemoglobin disorders.

The number of people with homozygous SS in Nigeria is high. This is thought to be due to the absence of carrier testing programs or premarital counseling/testing for prospective couples prior to marriage in a bid to reduce the prevalence of hemoglobin disorders. The universal neonatal screening program is an effective way to diagnosis the presence of hemoglobinopathy. Experience in Belgium has shown universal neonatal screening to be an excellent health education tool. ${ }^{15}$ Countries in Africa can benefit by implementing similar programs, as their development is pivotal to improving the health care of those affected by hemoglobin disorders. However, such program require major economic and organizational resources, which must be taken into account and balanced against other local health priorities. ${ }^{16}$ There is also a need for a sickle cell disease clinical care programs which should include: infection prophylaxis with penicillin and malarial prophylaxis; family training to identify early, severe, or persistent symptoms and increase awareness of the gravity of malarial crises; the evaluation of the patient's nutritional status and fluid intake; and education about the importance of regular medical visits.

The frequency of HbAS detected in this study (29.4\%) is consistent with previous studies in Nigeria and other African settings which observed a prevalence of $20 \%-40 \%$ in Africa, in general. ${ }^{11,17,18}$ Hemoglobin S, in comparison with $\mathrm{HbA}$, is thought to offer some protective role against Plasmodium falciparum malaria and conclusive evidence of this exists with Hemoglobin S (beta 6Glu- $>$ Val) and $\mathrm{HbC}$ (HbC; beta 6Glu- $>$ Lys), both occurring in sub-Saharan Africa. However, the mechanism(s) of the protection exerted remain(s) debatable for both hemoglobin variants $\mathrm{HbC}$ and HbS. Recently, an abnormal display of PfEMP1, an antigen involved in malaria pathogenesis, was reported on 
$\mathrm{HbAC}$ and $\mathrm{HbCC}$ infected erythrocytes that showed reduced cytoadhesion and impaired rosetting in vitro. ${ }^{16}$ We did not detect hemoglobin $\mathrm{C}$ either as homozygous HbCC, homozygous $\mathrm{HbAC}$, or as doubling homozygous for two abnormal hemoglobin HbSC. However a previous study in the Niger Delta $^{12}$ reported a prevalence of a $2 \%$ and $4 \%$, respectively, for $\mathrm{HbAC}$ and $\mathrm{HbSC}$. Similarly, a study of 204 individuals of a black ethnic background who were migrant Africans in Spain $^{19}$ described a $3.4 \%$ prevalence rate of $\mathrm{HbAC}$, while $0.5 \%$ had $\mathrm{HbCC}$.

We observed a gender-associated risk for hemoglobin S trait ( $\mathrm{HbAS}$ ) and $\mathrm{HbSS}$ of $63.3 \%$ and $6 \%$ for females versus $41.6 \%$ and $3 \%$ for males. The reason for this female gender susceptibility for abnormal hemoglobin $\mathrm{S}$ is unknown.

The frequency of $\mathrm{ABO}$ blood groups varies from race to race. We observed that (46\%) of our subjects were group $\mathrm{O}$, (26.6\%) were group A, $(23.6 \%)$ were group B while $(3.8 \%)$ were group $\mathrm{AB}(\mathrm{O}>\mathrm{A}>\mathrm{B}>\mathrm{AB})$. Among Western Europeans, the distribution of $\mathrm{ABO}$ blood groups indicates that $46 \%$ are group $\mathrm{O}, 42 \%$ are group $\mathrm{A}, 9 \%$ are group $\mathrm{B}$ and $3 \%$ are group $\mathrm{AB}(\mathrm{O}>\mathrm{A}>\mathrm{B}>\mathrm{AB})$. However, some Eastern Europeans have a higher proportion (up to $40 \%$ ) of group B blood, while pure American Indians belong exclusively to blood group O. ${ }^{18}$ American blacks generally demonstrate frequencies of $\mathrm{O}, \mathrm{A}, \mathrm{B}$, and $\mathrm{AB}$ blood groups of $49 \%, 27 \%$, $20 \%$ and $4 \%$, respectively $(\mathrm{O}>\mathrm{A}>\mathrm{B}>\mathrm{AB}) .{ }^{20} \mathrm{~A}$ previous report which focused on the Yoruba and Hausa ethnic groups in Nigeria by Worlledge et $\mathrm{al}^{21}$ indicated that $58 \%$ were group O, 21\% were group A, 17\% were group B and 2\% were group AB. Previous reports are in agreement with the frequencies obtained in this study and confirm that group $\mathrm{O}$ is the predominant $\mathrm{ABO}$ blood group. However an exception to this was observed among the Gwari tribe of Abuja and the Rubuka tribe of the Plateau state of Nigeria in which group $B$ was the predominant $\mathrm{ABO}$ blood group. The high frequency of group $\mathrm{O}$ observed in our study among the people of the Niger Delta provides an advantage in terms of availability of blood for transfusions, especially in emergencies. Blood group $\mathrm{O}$ individuals lack $\mathrm{ABO}$ blood group antigens on their red cell and thus their blood can be given to people of blood groups A, B and AB. However, some level of caution has to be exercised since the plasma of some group $\mathrm{O}$ blood individuals is known to contain high titer of potent $\mathrm{A}$ and $\mathrm{B}$ immune hemolytic antibodies (hemolysins). Routine hemolysin testing should be carried out on all group $\mathrm{O}$ blood samples to allow those containing high titer hemolysin to be reserved specifically for group $\mathrm{O}$ patients. Those samples which are negative for high titer hemolysin could be given to groups $\mathrm{A}, \mathrm{B}$, and $\mathrm{AB}$ individuals in emergency situations, where $\mathrm{ABO}$ group specific units are not available, to reduce the risk of transfusion reaction.

The frequency of $\mathrm{RhD}$ antigen in the present study was $93 \%$ while negativity accounted for the remaining $7 \%$ of the study population. This finding aligns with the $96.7 \%$ positive rate recorded by Ibos by Ukaejiofor et $\mathrm{al}^{22}$ $96.77 \%$ documented by Jeremiah ${ }^{23}$ in Port Harcourt, $96.6 \%$ by Pramanik et al ${ }^{24}$ in Nepal, $94 \%$ by Mwangi ${ }^{25}$ in Kenya, $93 \%$ by Bashwari et $\mathrm{al}^{26}$ in the Eastern region of Saudi Arabia, and $92.8 \%$ by Sarhan et $\mathrm{al}^{27}$ in Southwest of Saudi Arabia. This percentage of $\mathrm{RhD}$ negative observed in our study $(7 \%)$ is much lower than the prevalence rate of $\geq 14 \%$ RhD negative phenotype observed in studies among Caucasians. ${ }^{28,29}$ The obstetric implication of the low prevalence of D-negative in the Niger Delta population is that $\mathrm{RhD}$ alloimmunization problem may be of a much smaller magnitude than it is in most western countries. The Rhesus blood group system is the second most clinically significant red cell antigen system after the ABO blood group system. This is because a substantial proportion of the population lacks the major Rh antigen known as D. In such individuals, the likelihood of becoming sensitized to the $\mathrm{D}$ antigen following exposure by transfusion of $\mathrm{RhD}$ positive red cells or during pregnancy involving a Rhesus positive fetus is very high and the antibody $\mathrm{D}$ produced as a result of such immunization has serious clinical effects including hemolytic disease in the newborn and/or transfusion reactions. In this study we have observed a significantly higher prevalence of the sickling gene and a lower prevalence of $\mathrm{RhD}$ negative blood group compared to values reported among Caucasians.

Knowledge on the distribution of the various blood groups as well as abnormal hemoglobin variants is vital in the safe rendering of transfusion services, civic registration, and forensic medicine. As mentioned above, carrier screening and mutation identification can become the cornerstones of any prevention program for the hemoglobin disorders. It can also help in the formulation of genetic counseling policies to help prospective couples make informed decisions in an effort to reduce the sickling gene pool in the Niger Delta of Nigeria.

\section{Acknowledgments}

We thank the students of the Rivers State University of Science and Technology who served as subjects for this study and all the staff of the Laboratory Department of Omoku General Hospital for their collaboration. 


\section{Disclosures}

The authors report no conflicts of interest in this work.

\section{References}

1. Weatheral DJ. Genetic disorders of hemoglobin. In: Hoffbrand AV, Lewis SM, Tuddenham EGD, editors. Postgraduate Haematology. 4th ed. London, UK: Arnold Publishers; 2001:91-119.

2. Okpala I, Thomas V, Westerdale N, et al. The comprehensive care of sickle cell disease. Eur J Haematol. 2002;68:157-162.

3. Richard AW. Textbook of Black Related Diseases. New York, NY: McGraw Hill; 1979.

4. Lewis RA. Sickle cell: Clinical Features in West Africans. Accra, Ghana: Ghana University Press; 1970.

5. Pramanik T, Pramanik S. Distribution of ABO and Rh blood groups in Nepalese Medical Students: a report. East Mediterr Health. 2000;6:156-158.

6. Conteras M, Lubenko A. Immunohaematology: Introduction. In: Hoffbrand AV, Lewis SM, Tuddenham EGD, editors. Postgraduate Haematology. 4th ed. London, UK: Arnold Publishers; 2000:165-181.

7. Knowles S, Poole G. Human blood group systems. In: Murphy MF, Pamphilon DH, editors. Practical Transfusion Medicine. 1st ed. London, UK: Blackwell Science; 2002:24-31.

8. Brown BA. Hematology: Principles and Procedures. 6th ed. Philadelphia, PA: Lea and Fibiger; 1993.

9. Judd JW. Methods in Immunohematology. 2nd ed. Durham, NC: Montgomery Scientific Publications; 1994.

10. Brecher M. Technical Manual. 14th ed. Bethesda, MD: American Association of Blood Banks; 2002.

11. Sinou MT. Antenatal screening of sickle cell disease. 8th postgraduate course for training in reproductive medicine and reproductive biology. Cameroon, 2003.

12. Egesie UG, Egesie OJ, Usar I, Johnbull TO. Distribution of ABO, Rhesus and hemoglobin electrophoresis among the undergraduate students of Niger Delta State University, Nigeria. Niger J Physiol Sci. 2008;23:5-8.

13. Nwafor A, Banigo BM. A comparison of measured and predicted hemoglobin genotype in a Nigerian population in Bonny, Rivers State, Nigeria. J App Sci Env Manag. 2001;5:79-81.

14. Moormann AM, Embury PE, Opondo J, et al. Frequencies of sickle cell trait and glucose-6-dehydrogenase deficiency differ in highland and nearby lowland malaria-endemic areas of Kenya. Trans $R$ Soc Trop Med Hyg. 2003;97:513-514.
15. Gulbis B, Cotton F, Ferster A, et al. Neonatal haemoglobinopathy screening in Belgium. J Clin Pathol. 2009;62:49-52.

16. Tshilolo, L, Kafando, E, Sawadogo M, et al. Neonatal screening and clinical care programmes for sickle cell disorders in sub-Saharan Africa: lessons from pilot studies. Public Health. 2008;122:933-941.

17. Reid HL, Famodu AA. Spectrophotometric quantification of hemoglobin fraction in heterozygous sickle cell trait (HbAS). Med Lab Sci. 1988;45:143-145.

18. Fleming AF, Lehman H. Sickle Cell Disease: A Handbook for the General Clinician. Edinburgh, UK: Churchill Livingstone; 1982.

19. Verra F, Bancone G, Avellino P, Biot I, Simpore J, Modiano D. Hemoglobin $\mathrm{C}$ and $\mathrm{S}$ in natural selection against Plasmodium falciparum malaria: a plethora or a single shared adaptive mechanism? Parassitologia. 2007;49:209-213.

20. Las HMG, Junca PJ, Feliu FE, Rovira FJM, Gil GM. Haemoglobinopathies and glucose-6-phosphate dehydrogenase deficiency in the sub-Saharan immigrant population of the Center and South Maresme region, Catalonia, Spain. Med Clin. 2008;131:5-9.

21. Worlledge S, Ogiemudia SE, Thomas CO, Ikoku BN, Luzzatto L. Blood group antigens and antibodies in Nigeria. Ann Trop Med Parasitol. 1974;68:249-264.

22. Ukaejiofor EO, Okonkwo WC, Tagbar EN, Emeribe AO. Blood Transfusion in the Tropics. Nigeria: Salem Press; $\mathrm{ABO}$ and Rhesus in a Nigerian population; 1996:1-22.

23. Jeremiah ZA. Abnormal hemoglobin variants, $\mathrm{ABO}$ and $\mathrm{Rh}$ blood groups among students of African descent in Port Harcourt Nigeria. Afr Health Sci. 2006;6:177-181.

24. Pramanik T, Pramanik S. Distribution of ABO and Rh blood groups in Nepalese medical students: a report. East Mediterr Health J. 2000;6:156-158.

25. Mwangi J. Blood groups distribution in an urban population of patient targeted blood donors. East Afr Med J. 1999;76:615-618.

26. Bashwari LA, Al-Mulhim AA, Ahmad MS, Ahmed MA. Frequency of $\mathrm{ABO}$ blood groups in the Eastern region of Saudi Arabia. Saudi Med J. 2001;23:1008-1012.

27. Sarhan MA, Salem KA, Bin-Dajem SM. Distribution of ABO blood groups and Rhesus factor in Southwest Saudi Arabia. Saudi Med J. 2009;30:116-119.

28. Bergstrom S, Pereira C, Hagstrom U, Safwenberg J. Obstetric implications of Rhesus antigen distribution in Mozambican and Swedish women. Gynecol Obstet Invest. 1994;38:82-86.

29. Cerny T, Fey MF, Oppliger R, et al. Prevalence of the Rhesus - negative phenotype in Caucasian patients with small-cell lung cancer (SCLC). Int J Cancer. 2006;52:504-506.
Pathology and Laboratory Medicine International

\section{Publish your work in this journal}

Pathology and Laboratory Medicine International is a peer-reviewed, open access journal focusing on innovative basic research and translational research related to pathology or human disease. The journal includes original research, updates, case reports, reviews and commentaries on current controversies. The Academic Sponsor

\section{Dovepress}

of this journal is the Chinese American Pathology Association (CAPA). The manuscript management system is completely online and includes a very quick and fair peer-review system. Visit http://www.dovepress.com/testimonials.php to read real quotes from published authors. 